\title{
MOWY ŚWIĘTEGO AUGUSTYNA (Sermones de Vetere Testamento: XVI, XXXV, XXXIX)
}

\author{
W $s$ t $\mathrm{p}$
}

Dzisiejszy czytelnik może w kazaniach św. Augustyna znaleźć różne treści, gdyz święty zawarł w nich dużą część swojej wiedzy teologicznej. Poświęcił wiele miejsca sprawom Kościoła swoich czasów, jak również przejawił głębokąa znajomość zakamarków ludzkiej natury, w których człowiek bardzo często się gubi. Ta właśnie ostatnia warstwa, szczególnie dobrze znana św. Augustynowi ze względu na rozterki jego młodości, jest widoczna bardzo wyraźnie w kazaniach. Siła, a można powiedzieć, upór, z jakim próbuje przekonać słuchacza o tym, ze lepiej być dobrym człowiekiem $i$ żyć dobrze, niż być złym 1 wieść życie nikczemne, wskazują, że problem poprawy natury ludzkiej - co jest możliwe jedynie przez współdziałanie z łaską Bozą - był myślą przewodnią jego nauczania.

Kazania są polem, na którym biskup rozprawia się ze wszystkimi negatywnymi zjawiskami obyczajowości chrześcijańskiei. Czyni to na forum publicznym, przed szerokim gronem wiernych, dlatego tez d́w. Augustyn rzetelnie przygotomywaz sie do ich wygkaszania. 'Był przeciez doskonałym retorem, ale 1 na tyle dobrym psychologiem, by całego cięzaru powodzenia swych mów nie opierać jedynie na starannie opracowanej formie. Zwłaszcza, ze zdawał sobie sprawę z niedoskonałości słownego przekazu treści teologicznych. Dlatego tez prawie zawsze był niezadowolony ze swych kazań, o czym sam często mawiał ${ }^{1}$. Cel, który poprzez nie chciał osiągnąé, mógł być zdobyty przede wszystkim dzięki komunikatywności i sile argumentu. W swym dziele "0 nauce chrześcijańskiej" pisał: "Usilnie

1 De catechisandis rudibus I 2,3 , CCL 46,122 , POK 10,4 . 
- to starać się nalezy, abyśmy byli zrozumiani nie tylko $w$ rozmowie z jednym lub wieloma rozmówcami, lecz przede wszystkim cdy sie przemawia do ludun ${ }^{2}$.

Mowy, które dajemy wolskim przekładzle są llustracją wyzej poruszonych spraw. Kazania te sa traktatami egzegetycznymi odnoszacymi się do Starego Testamentu, w których biskup Hippony omawia ważne zagadnienia natury moralnej ${ }^{3}$. Dobro 1 zło, cnota 1 grzech oto zagadnienia, jakimi zajmuje sie św. Augustyn w przełozonych przez nas kazaniach.

W kazaniu XVI, którego data wygłoszenia jest nam blizej niezrana, radzi, jak nalezy korzystać z rzeczy tego świata. One to, jak mówi, "kuszą nas 1 pociagają", ale nie trzeba ich unikać w sposób całkowity. Wszystko bowiem, co istnieje, pochodzi od Boga i jako takie ma być w pełni wykorzystane przez człowieka - ale wakim celu jedynie, by zaskarbić sobie nagrodę wiebie. W kazaniu XXXV, nygłoszonym prawdopodobnie przed 410 r., stara się udowodnić, ze dobroć 1 mądrość Idąc ze sobą w parze przynosza korzyść wszystkim. Zło zawsze skończy się sromotą, ale dla tego, kto się nim nie brzydzi. W kazaniu XXXIX św. Augustyn roztacza przed wiernymi obraz mozliwośc1, jakimi dysponuje człowiek, by s'tać się posiadaczem nKrólestwa Niebieskiego". Zgodnie z obietnicą Zbawiciela, kubek zimnej wody ofiarowany bliźniemu jest ceną, za która każdy jest w stanie nabyć zbawienie. Bîskup Hippony celowo, jak się wydaje, przywołuje to waśnie miejsce z Ewangeli1, aby zestawiając przez kontrast śmiesznie niską cenę z tym, co można za nią otrzymać, uświadomić swym wiernym jak mało trzeba, by dostąpić zbawienia.

Przekładu dokonano z lacínskiego tekstu krytycznego, wydanego w 1961 r. przez C.Lambota w 41 tomie "Corpus Christianorum".

B 1 b 110 \& a 1 i a:

A.Kunzelmann, Die Chronologie der Sermones des hl.Augustinus, In: Miscellanea Ágostiniana, II, Roma 1931, 417-520. C.Lambot, Collection antique de Sermons de saint Augustin, "ilevue Bénédictine" 57/1947/ 89-108. Tenże, Critique interne et sermons de saint Augustin, "Studia

2 De doctrina christiana IV 10, 25-26, CCL 32, 133-134; por. PSP $22,111$.

3 Por. E.Stanula, Wstęp, w: Ś .Augustyn, Wybór mów, Warszara 1973 PSP 12, 9-20. 
Patristica" 1/1957/ 112-127. C.Mohrmann, Das Wortspiel in den augustinischen Sermones, in: Etudes sur de latin des Chrétiens, Roma 1958, I, 323-349. A, de Veer, La date des sermons de saint Augustin, "Revue des études Augustiniennes" 15/1969/ 241-246. E. Stanula, Wstęp, พ: Św. Augustyn, Wybór mów, Warszawa 1973, 9-20, P.P. Verbraken, Etudes critiques sur les Sermons authentiques de saint Augustin, Instrumenta Patristica XII, Stenbrugis 1976.

\section{MOWA XIV}

Do słów: "Jaki jest człowiek, który chce żyć $i$ pragnie oglądać dni szczęśliwe"/Ps $33,13 / \mathrm{x}$

1. Kiedy Duch Boży powołał rodzaj ludzki do istnienia nakazując, co należy czynić, i zapowiadając, czego należy oczekiwać, najpierw skierował naszą myśl ku nagrodzie, abyśmy czynili to, co nakazane, bardziej kochając dobro niż bojąc się zła. "Jaki jest człowiek" - rzecze - "który chce żyć i pragnie oglądać dni szczęśliwe"? W ten sposób pytano, jakim on jest, jakby można było się domyślać, jakim on nie jest. Któż bowiem nie chce żyć? Któż nie chce oglądać dni szczęśliwych? Posłuchaj, co dalej następujel Posłuchaj, człowiecze,czegokolwiek chcesz i pragniesz. Posłuchajcie więc, wszyscy ludziel "Powściągnij swój język od złego, a wargi swoje od słów podstępnych, odstąp od złego, czyń dobro, szukaj pokoju i idź za nim" /Ps 33,14/. Z tych wszystkich słów początkowe są nakazem, a końcowe zapowiadają nagrodę. Nakazano nam bowiem, abyśmy powściągnęli język od zła, a wargi od słów podstępnych; abyśmy odstąpili od zła 1 czynili dobro, szukali pokoju i za nim podążali. Czym bowiem jest ów pokój, jeśli nie tym, czego światu brakuje? Czym jest ów pokój, jak nie tym, czego nie ma w tym życiu, które w porównaniu z tamtym życiem w ogóle nie jest życiem. Nie o tym przecież życiu mówi psalm: "Jakim jest człowiek, który chce żyć", lecz zachęca do zatrzymania

x CCL 41, 213-216. 
tego Innego życia, lub do tego, by je rozwijać. Albowiem i to ziemskie życie może być długie /choć nie może być wieczne/, a człowiek może dojść do tego drugiego życia przez to ziemskie. Dlatego jak pragnie, by było ono długie, tak samo się stara, by było dobre. Na ile zatem moze byé dłucie to zycie, które przecież ma się kiedyś skończyć? Jaka jest miara długości tego życia? To, co było długie, będzie niczym, bo nie stanęło; gdy istniało, nie rozwinęło się, gdy wydłużało się, a przez dodanie nie wzrosło, bo idąc naprzód, przemijało.

2. Chociaż więc jesteś miłośnikiem długiego życia, kochaj również dobre życie. Gdybyś bowiem zechciał żyć źle, życie twoje nie będzie dobrem, lecz pasmem zła. Zobacz, jaki jesteś niedorzeczny 1 przewrotny, gdy mówisz, że kochasz bardziej życie niż majątek, a zarazem wolisz dobrą posiadłość niż dobre życie. Bowiem oszukując czynisz życie złem. A oszukujesz, bo pragniesz zdobyć majętność i zabiegasz o nią $i$ nadmiernie jej pragniesz. Gdyby ci powiedziano, gdyby zapytano, czy wolisz być pozbawiony posiadłości - tracąc ją, czy złego życia - umierając, odpowiedziałbyś, że skoro nie możesz zatrzymać obu, gotów jesteś na to, by zabrano ci posiadłości. Dlaczego więc nie kocha się w ten sposób życia, żeby ono było również dobre; ono, które bez twego udziału nawet jako złe bierze górę nad wszystkimi twoimi dobrami? Z pewnością pragniesz, aby było ono długie, choćby miało być złe. Staraj się, by było dobre, a nie bój się o to, że może być krótkie. Jeżeli życie twoje będzie dobre dzięki twemu staraniu, to zakończy się bez żadnych obaw. Właśnie o to życie z pewnością pyta ten, kto mówi: "jaki jest człowiek, który chce żyć i pragnie oglądać dni szczęśliwe". Apostoł zachęca, abysmy dobrze wykorzystali czas życia, bo dni są złe. Co oznacza "wykorzystać czas" jeśli nie to, że trzeba odnajdywać i zdobywać wieczne przestrzenie czasu nawet ze strata własnych dóbr. Stąd i Chrystus przestrzega, mówiąc: "Temu, kto chce prawować się z tobą 1 wziąć twoją szatę odstąp i płaszcz" /Mt 5,40/. Abyś na odpoczynek obrócił czas, który strawiłbyś na kłótni o jakieś ziemskie sprawy.

3. Następne zdania uczą, że Duch Boży mówiąc: "jaki jest człowiek, który chce żyć i pragnie oglądać dni szczęśliwe" nie rozprawia - tym życiu i o dniach tego czasu. Dołącza bowiem takie wskazania, którym będąc posłuszni, moglibyśmy mieć życie i dni dobre; jednak dla ich wypełnienia należy utracić właśnie to życie $i$ te dni, które 
pędzimy. A zatem, jeśli w powyzszym powiedzeniu: "jaki jest człowiek, który chce żyć" będziemy myśleli o życiu obecnym 1 ze względu na nie wypełniali nakazy, które sa z nimi związane, cóź zrobimy, jeśli ktoś zły będzie nam groził śmiercią? Czy nie będziemy mówili fałszu? Zaiste, gdybyśmy wykonali, co się tu zaleca: "powściagnij swój Język od zła, a wargi od słów podstępnych"/Ps 33,14/, aby odrzucić to fałszywe świadectwo ze względu na powyższe przykazanie, będziemy uchodzić za ludzi naiwnych. Pragnienie zachowania życia pociąga za sobą obowiz̨zek zachowania i przykazań; nawet gdybyśmy dla lch zachowania mieli zginąć. Gdybyśmy więc rozumieli życie jako szczęśliwe na wieki, które po tym życiu da Bóg tym, którzy Mu są posłusza1. o których Pan powiedział: "Jeśli chcesz osiągnąć życie wieczne, zachowuj przykazania" /Mt 19,17/, wtedy zapytani: "jaki jest człowlek, który chce żyć" - odpowiemy, że chcemy żyć, nawet jeśli dawać będziemy świadectwo prawdzie w obliczu prześladowań; lekcewazymy śmierć na tym świecie i osiągamy życie w niebie.

4. Poznajemy to na podstawie dobrych dni. Gdybyśmy bowiem ze względu na obecny czas, który zwie się szczęśliwym, a takim nie jest, gdyz wiedzie do obzarstwa, w otchłań opilstwa i zbytku, do najszkaradniejszych rozkoszy ciała - gdybyśmy więc ze względu na te dni jako szczęśliwe przyjęli przykazania, aby nie kalać ust kłamstwem, a do tego właśnie najbardziej takie czasy zmuszają swych wielbicie11, takie dni odrzuci ten, który nie kłamie. Cóż innego bowiem znaczy "kłamać" jak nie wypowiadá́ ustami coś innego niż to, co kryje się w sercu. Wielu jest pochlebców, którzy po to, by nie zostali odsunięci od obfitych stołów, schlebiają posługując się kłamstwem, a powstrzymują się od tych rzeczy, jeśl1 kochając Boga mówią prawdę. Zatem ze względu na te dni, które uwaźają za dobre, ponieważ ich pożądają, mówią fałszywie, a zaprzecza się im, gdy nie mówią Pałszywie.

Inne są więc dni dobre, o których powinniśmy pamiętać, jeśli pragniemy je widzieć, abyśmy powstrzymali język od fałszu i nie mówili kłamstwa. Nie są to dni tego czasu; nie ma loh niebo, które przemija, lecz które trwa. Nie zna ich ziemia śmiertelnych, lecz ziemia nieśmiertelnych. Każdy, kto je poznał 1 pokochał, powstrzyma język od zła; gdyby strach przed śmiercią zmusił go do zła, usta jego nie wypowiedzą kłamstwa; a gdyby dni fałszywie dobre zapraszały do zła, niech odwróci się od zła/wplecionego/między dobrem 
i niech czyni dobro pomiędzy złem. Niech szuka pokoju, którego nie ma na ziemi; niech szukają go w Tym, który stworzył niebo i ziemię.

5. Zatem, bracia, pożądajcie i pragnijcie dni szczęśliwych, pragnijcie oglądać dni dobre, w których nie będzie żadnej nocy; pragnijcie życia, w którym nie trzeba będzie obawiać się dnia złego, pragnijcie dni dobrych, w których życie nigdy się nie skończy. Lecz jeśli takiej nagrody pragniecie, nie zaniedbujcie uczynków, które ją niosá. Wytrwale poszukujcie tego pokoju. Szukajcie go zatem po omacku w obliczu Boga i nie dajcie się zwieść. Co jest bowiem z waszych rąk, jeśli nie dobre dzieło? Co oznacza "w nocy", jeśli nie "w udręczeniu? Co oznacza "w obliczu", jeśli nie w "czystości sumienia"? Tak żyjąc i tak kochając będziecie oglądać Boga i w Nim będziecie mieli życie bez żadnych braków, dni dobre bez ciemności, pokój bez zakłóceń.

\section{MOTYA XXXV}

Do słów: "jeśli mądry będziesz, mądrość tobie i twoim bliskim przyniesie pożytek; jeśli natomiast złym będziesz, sam poniesiesz szkodę"/Prz $9,12 / x$

1. Gdyby słowa Boskie były przyjmowane $z$ uwaga, mogłyby poruszyć być może i taką treścią: "Synu, jeśli mądry będziesz, mądrość tobie i twoim bliskim przyniesie pożytek; jeśli natomiast złym będziesz, sam poniesiesz szkodę". W jaki sposób możemy się wprost o tym przekonać? Wtedy właśnie, gdy cieszymy się dobrem bliźniego, a jego przewrotnością się smucimy. Lecz, jeśli powiedziano to ku zaleceniu, że mądrość jest korzyścią zarówno dla rozumnego jak 1 dla tych, których do mądrości nakłaniano, na jakiej zatem podstawie można mówić, że gdy kto źle czyni, sam poniesie szkodę, skoro przekonująco brzmią słowa: "Wskutek złych rozmów psują się dobre obyczaje"/1 Kor 15,33/. Cóż bowiem innego mówi ten głos miłości? "Gdy cierpi jeden członek, współcierpią wszystkie inne, podobnie gdy chwalony jest jeden członek, wszystkie pozostałe się z·nim współradują" / 1 Kor 12,26/. Jak więc może być prawdą zalecenie: "Synu,

x CCL 41, 429-431. Komentowana sentencja wg Septuaginty . 
jeśli mądrym będziesz, mądrość tobie i twoim bliskim przyniesie pożytek, jeśli zaś złym będziesz, sam poniesiesz szkodę". Czy będę weselić się dobrem tego, którego złem nie mogę się smucić? Jak może cieszyć mnie jakiś napotkany człowiek, który może być zgubiony moją beztroską? Czy nie będą się radować pozostałe członki, gdy będziesz mądrym, zdrowym członkiem? Jakim sposobem zły sam poniesie szkode, skoro przecież z chorym członkiem współczują inne?

2. Trzeba rozwiązać to zagadnienie, gdyż w przeciwnym wypadku będzie ono nas niepokoiło. Uczynić zaś to można w oparciu o Pana oraz trzymanie się tej niezachwianej, najpełniejszej prawdy, że ani dobro jednego człowieka nie może być dobrem drugiego, ani zło złego nie może być złem innego. Przecież Apostoł mówi: "Każdy poniesie własny ciężar" /Gal 6,5/. A gdzie indziej: "Tak więc każdy z nas sam o sobie zda sprawę" /Rz 14,12/, a wtedy "powód do chluby znajdzie tylko w sobie samym, a nie w innym"/Gal 6,4/. Zostało też powiedziane przez proroka Ezechiela: "Oto wszystkie osoby są moje: tak osoba ojca, jak osoba syna. Umrze tylko ta, która zgrzeszyła" /Ez 18, 4/, a całe to miejsce wyjaśnia w ten sposób, że ukazuje, iż dobrzy rodzice nie poniosą kary za złych synów, ani dobrzy synowie za złych rodziców. Te wspaniałe zdania właśnie dla nas samych najpierw zostały powiedziane. Pozostaje tylko się przyjrzeć, co inne zalecenia zawierają, $i$ z rozwagą rozstrzygnąć, czego pożądamy ze względu na nasze zbawienie, a czego ze względu na bliźniego. Jeśli jesteś dobry, to dobrem swoim, a nie kogoś innego. Podobnie, jeśli cieszysz się swoim dobrem, to 1 dobrem drugiego będziesz się radował; nie dobrem od niego pożyczonym, lecz wzajemnym szacunkiem. Zatem, jeśli jesteś złym, to też złem swoim, a nie cudzym. Tylko, jeśli siebie swoim złem nie zadowolisz, to tym bardziej twoich bliźnich. Nikt bowiem nie będzie się cieszył jak ty sam. Cieszysz się oczywiście ze srogiego ucisku nieprzyjaciela, ale nie przychodzi on do ciebie z zewnątrz, lecz jest w tobie. By łatwiej ciebie zwyciężyć, pochlebia ci. I tak to, czego nienawidzisz, zwalczasz otwarcie, a to, co lubisz, niszczy cie w sposób straszliwy. Prawdą są bowiem słowa Boże: "Kto ukochał zło, jest wrogiem swej duszy"/Ps 10,6/.

3. Z tego wynika, że człowiek dobry cieszy się z dobra innego, a smuci się ze zła tym dobrem, którym jest dobry. Przez to, taki bliźni, który prawdziwie może nim byé nazwany - tj. taki, który ciebie uważa za bliźniego i odnosi się do ciebie z miłością - taki 
przyniesie pożytek 1 sobie 1 tobie, jeśli będzie mądry. Jeśli natomiast złym będziesz, nie on, lecz ty "sam poniesiesz szkodę". Nikt bowiem nie będzie zły z powodu twojego zła, lecz może ci jedynie współczuć. Zasmuca go twoja złość, lecz przez to karze nie podlega. Smutek z powodu zła nie jest uczestnictwem w niesprawiedliwości. I tak człowiek zły nie weepor z dobrym, ale sam "poniesie szkodę", ponieważ ten smutek, który ma człowiek dobry z twego powodu,. ma on ze względu na własne dobro $i$ na twoje zło. Ten smutek jest dla niego zapowiedzia pocieszenia, a dla ciebie zguby. Ciebie potępia, jego wieńczy; ciebie upokarza, jego wywyższa. Jest bowiem napisane: "Posłuszni bądźcie przełożonym waszym; oni strzegą dusz waszych 1 będa musieli z tego zdać sprawę; aby mogli to uczynić z radością, nie ze smutkiem, gdyż i dla was nie byłoby to korzjstne"/Hbr 13,17/. Nie trzeba więc, byście się zbytnio ich smutkiem obciażali. Dobrze jednak, jeśli smucicie się z niesprawiedliwości. Dobrych bliźnich szanuj $i$ bądź dobry właśnie twoim dobrem, nie tamtych, 1 tym które ty masz nie dzięki sobie, lecz za zarządzeniem Boga! "Cóz bowiem masz, czegoś nie otrzymał"? / 1 Kor 4,7/. A także: "jéli mądrym będziesz, mądrość tobie $i$ twoim bliźnim przyniesie poźytek", dla których dobrem jest cieszenie się z twojej dobroci. "Jeśli złym będziesz, sam poniesiesz szkodę", a nie ci, dla których dobrem jest smucente sie z twojego zła.

\section{MOWA XXXIX}

Do słów: "Nie zwlekaj z nawróceniem się do Boga, ani nie odkładaj tego z dnia na dzień" $/$ Syr $5,7 / /^{x}$

1. Usłyszeliśmy, bracią, co mówi Bóg przez proroka: "Nie zwlekaj z nawróceniem się do Pana, ani nie odkładaj tego z dnia na dzień. Nagle bowiem przyjdzie Jego gniew i straci cię w dniu wymiaru sprawiedliwości". Bóg ci oblecał, że w dniu, w którym się nawrócisz, zapomni o twojej nieprawości. Lecz czy obiecał ci życie w dniu jutrzejszym? Czy Bóg ci je obiecał, czy obiecał ci je wróżbita, by Bóg potępił i ciebie 1 jego? Bóg pozostawił dzień śmierci nieznanym, aby każdy w nadziei myślał o swoim końcu. W tym się pojawia miłosierdzie Boże, że człowiek nie wie, kiedy umrze. Dzień ostatni

$\times$ CCL 41, 489-492. 
jest ukryty, abyśmy przez wszystkie czuwali.

2. Lecz świat nas pociąga i dookoła kuszaz nas jego ponęty. Cieszy nas majątek, cieszy blask zaszczytów, cieszy strach przed władzą. To wszystko nas cieszy, ale posłuchajmy Apostoła: "Nic bowiem nie przynieśliśmy na ten świat, ani też nic nie możemy z niego wynieść" /1 Tym 6,7/. Nie ty powinieneś szukać zaszczytów, ale one ciebie. Zasiadaj zatem na miejscu niższym, aby ten, który ciebie zaprosił, mógł zaprowadzić cię na miejsce zaszczytniejsze. Jeśliby nie zechcial tego uczynić, spożywaj posiłek tam, gdzie usiadłeś, "ponieważ nic na ten świat nie wniosłeś". Z cudzego jesz i jeszcze ci źle? Siadaj gdziekolwiek i jedz! Może powiesz, że jesz ze swego? Posłuchaj Apostoła: "Nic nie przyniosłeś na ten świat, nic teź wynieść nie możesz". Przyszedłeś na świat i zastałeś pełny stół, albowiem: "do Pana należy ziemia $i$ wszystko, co ją napełnia"/Ps $23,1 /$.

3. "Którzy bowiem chcą się stać - rzecze - bogatymi"/1 Tym 6,9/. Nie powiedział: którzy są bogatymi, lecz: "którzy chcą się stać bogatymi". Oskarżył pożądanie bogactw, a nie ich posiadanie; "ci, którzy chcą się stać bogatymi, wpadają w pokusę, w zasadzkę oraz liczne szkodliwe i nierozumne pożądania. One to pogrążają ludzi w zgubę i zatracenie". Pieniądze cieszą. Nie boisz się ich? Dobrą rzeczą są pieniądze i to duże pieniądze. "Wiodą na pokuszenie". Nie lękasz się ich?" One to pogrążają ludzi w zgubę i zatracenie. I nie czujesz jeszcze lęku? A pragnienia te dokąd prowadzą? Pogrążają ludzi w zgubę i zatracenie. Czyż dotąd głuchy jesteś? Nie boisz się zguby i zatracenia? Chrapiesz, chociaż Bóg tak grzmi?

4. Innym, 'którzy są już bogaci, Apostoł daje taką radę: "Bogatym tego świata nakazuj, aby nie byli wyniośli"/1 Tym $6,17 /$. Istotą zła jest pycha, dlatego nie jest łatwo bogatemu jej uniknąć. Usuń pychę, a bogactwo ci nie zaszkodzi. Dlatego też uważaj na to, co powinieneś czynić, a nie ominie cię nagroda u Boga. "Aby nie byli wyniośli". Odrzuć ten błąd. I nie pokładaj nadziei w niepewności bogactw. Usuń $i$ ten błąd. Gdy tego dokonasz wypełniaj dobre uczynki, o których słyszysz: "Niech czynią dobrze, bogacą się w dobre czyny. Niech nie pokładają nadziei w niepewności bogactwa, lecz w Bogu, który nam obficie udziela wszystkiego do używania" /1 Tym 6,18/. Gdzie więc mają złożyć nadzieję? "W Bogu żywym, który nam 
udziela wszystkiego obficie do używania". Bóg daje świat biednemu i bogatemu. Czy ten, który jest bogaty ma jeść podwójnie? Patrzcie i uważajcie, że nawet ubodzy nasyceni Bożymi darami zasypiają. Kto was żywi, żywi ich przez was.

5. Nie należy więc kochać pieniędzy, lecz jeśli już je macie, dobrze je wykorzystujcie. Bądźcie bogaci wy, którzy je macie. Lecz w co bogaci? "W dobre uczynki. Niech będą hojni, społeczni" /1 Tym 6,19/. Tu już skąpstwo przeszkadza. Posłuchaj zdania następnego: "Niech będą hojni i społeczni". Podobnie jak woda spływa, chłodzi, wstrzymuje oddech i głosi: "nie darmo pracuję". Nieszczęsny człowieku, chcesz zmarnować swoją pracę? oto umrzesz i nic nie możesz zabrać ty, który nic na ten świat nie wniosłeś. Czy już teraz nie straciłeś swojej pracy, ponieważ nic z niej nie weźmiesz? Posłuchaj więc rady Boga. Nie możesz się lękać o to, że powiedział: "Niech będą hojni i społeczni". Słuchaj, co dalej następuje. Oczekuj; nie zamykaj drzwi przede mną, ani nie osłabiaj wrażliwości serca swegol oczekuj! Czy chcesz zrozumieć słowa: "Niech będą społeczni i hojni", że nie utracisz tego i tylko tego? "Niech odkładają - rzecze - do skarbca dla siebie samych dobrą podstawę na przyszłość, aby osiągnęli prawdziwe życie" /1 Tym 6,19/. To życie, którym tu żyjesz, jest fałszywe. Żyjesz jak we śnie. Jeśli tu żyjesz jak we śnie, to czy zamierzasz czuwać dopiero, gdy umrzesz, a wtedy niczego nie znajdziesz w swoich rękach. Gdyby żebrak tak spał, że we śnie widziałby wielki spadek, to nic nie byłoby dla niego szczęśliwszego, zanim się obudzi. Widziałby we śnie, jak chwyta rękani wspaniałe szaty i kosztowne dzbany, jak przechadza się po wspaniałych komnatach, jak oddaje mu cześć wielka rodzina. Ocknął się i zapłakał. I, jak na jawie oskarża tego, który go okradł, tak oskarża tego, który go zbudził. Najdobitniej zostało to powiedziane w Psalmie: "śpią snem swoim - rzecze - i nic nie znajdą wszyscy mężowie bogaci w swoich rękach"/Ps $75,6 /$, gdy się obudzą.

6. Nic nie wniosłeś na ten świat i nic nie możesz stąd zabrać. Co zyskałeś tutaj, poślij ku górze, jeśli nie zamierzasz tego stracić. Daj Chrystusowi; On bowiem już tu chce to przyjąć. Czy stracisz, gdy dasz Chrystusowi? Nie tracisz, jezeli powierzasz słudze swemu, a czy stracisz, jeżeli dasz Panu? Nie tracisz, jeżeli powierzasz słudze to, co już zaoszczędziłeś, a myślisz, że zgubisz, co otrzymałeś od Pana? Ze względu na nas Chrystus stał się ubogi. 
Chrystus mógł nakarmić ubogich, których widział, tak jak Eliasza przez kruka. Jednak i swemu Eliaszowi Pan kruka zabrał. Nie dàł Eliaszowi, ale dał wdowie, aby ona oddała Eliaszowi / $1 \mathrm{Krl} 17,4-$ 16/. W ten wį̨ sposób Bóg czyni biednycil, nie chcąc, by oni posiadali; uczynił biednych, aby wypróbovać bogatych. Tak jest bowiem napisane: "Biedni i bogaci wychodzz naprzeciw" /Prz 22,2/. Gdzie się spotkaj̧a? W tym życiu. Jedni i drudzy są urodzeni: waajemnie się odnajdą i spotkajł. Kto "ich uczynił? - Pan". Uczynił bogatego, aby pomagał biednemu, i biednego, aby wypróbował bogatego. Niech każdy czyni wedle swej mocy! Niech jednak nie czyni tak, żeby sam cierpiał biedę! Nie o tym mówimy. To, na czym tobie zbywa, potrzebne jest innym. Słyszeliście, gdy czytaliśny Ewangelię: "Kto poda kubek świeżej wody do picia jednemu z tych najmiejszych ze względu na mnie, zaprawde powiadam wam, nie utraci swej nagrody" / Mt 10,42; Mk 9,40/. Pan przedstawił Królestwo Niebieskie jako możliwe do kupienia i zechciał, by cena za nie był kubek zimnej wody. Kto dużo ma, ten niech dużo czyni. Owa wdowa dała jałnużnę tylko z dwóch grosików /Mt 12,42/. Zacheusz oddał połowę majątku, a drugaz zachował dla naprawienia swych oszustw /£k 19,8/. Jałauzny pomagajz tym, którzy chca odmienić swoje życie. Dajesz je ubogiemu Chrystusowi, aby odkupić dawne grzechy. Jeśli bowiem dlatego dajesz, aby ci pozwolił bezkarnie grzeszyć, to nie karmisz Chrystusa, lecz starasz się znieprawić sędziego. Czyńcie więc jałnużnę dlatego, aby wasze prośby były wysłuchane i aby wam Bóg doponógł zmienić życie na lepsze. A wy, którzy odmieniacie to życie, odmieniajcie je na lepszel Poprzez jałmużnę i modlitwy niech będą wymazane dawne grzechy, a przyszłe dobra przyjda do was na zawsze!

Przełożyli, wstępem i komentarzem opatrzyli Małgorzata Saks i Stanisław Rączka

studenci Patrologii ATK

pod kierunkiem ks.dra Kazimierza obryckiego 